\title{
THE DOCTRINE OF FRUSTRATION AS APPLIED TO CONTRACTS.
}

A recent decision in the Circuit Court of Appeals of the $4^{\text {th }}$ Circuit ${ }^{1}$ points to the conflict, ever recurrent in the administration of the law, between the application of the fixed and defined rules of law and the attempt of individual judges to apply their own ideas of equity and justice to particular cases as they arise.

The opinion of the court in the Gans case, supra, is largely taken up with an argument designed to show the right and powen of the Court to "do justice" as the Court views it, and the result achicved by the decree of the Court is the establishment of the "Equities" between the contracting parties as the particular court thinks they should be established.

Circuit Judge Woods uses the following language:

"True, this is an inquiry into the equity of the matter, in the sense of inquiry into the justice of the controversy. But it is in no sense an inquiry belonging exclusively to a court of equity. Even. common law courts constantly decide causes on grounds of fraud, mistake, unjust enrichment, and other grounds sometimes thought of as peculiar to courts of equity. Courts of admiralty have often decided cases on the equities which arise incidentally in the exercise of their jurisdiction."

This case is a convenient starting point, affording as it does differences in point of view as to the manner and method of administering justice, from which to approach some recent decisions of no little importance to the evergrowing body of American Commercial Law.

The proper theory underlying the administration of the English Common Law, is that Judicial Decision should be founded on evidence and its boundaries should be within the evidence, and should not be in the twilight zone beyond the boundaries of evidence when the evidence fails to afford requisite certainty.

\footnotetext{
${ }^{2}$ Isles Steamshipping Co. v. Gans Steamship Line; decided November ${ }_{\text {, }}$ 102I; not yet reported.
} 
But in the most careful adherence to this theory of judicia! decision, the struggle of a rule of practical cliaracter to emerge irom the necessities of modern commerce and become recognized as a rule of law, is one fraught with interest.

The development of the rule itself will depend not only upon the circumstances in which the controversy calling for the application of the rule is involved, when presented to the Court, but also upon whether the particular court inclines more strongly toward a strict application to the evidence of the definite rules of law, or, impelled by an individual desire, toward arriving at the. "equities of the case" as they may appeal to the particular court at the time, disregarding or misapplying the definite rule of law, and thus plunging the rules of law into uncertainty.

The former method involves a nice adjustment or expansion of the reason of the rule to the solution of the question presented. by the cornbination of the facts in evidence.

The latter method generally results in the situation described by the phrase- "Hard cases make bad law."

Perhaps as good an illustration as any of the latter method will be found in the remarks of the District Court Judge, in the case now under discussion, during the oral argument:

"It depends, in fact, upon whether you are more interested in principles than in doing actual justice. Officially $I$ am bound by principles, but only officially. Where it is necessary for the preservation of some set of rules, it is a poor judge, when he finds himself faced by what appears to be a principle in a particular case, which leads in that case to the breaking of justice, does not take that principle up and turn it over and examine and squeeze it and press it, and see if, after all, whether the form in which it has sometimes been stated is the real principle or not. Sometimes he finds it is, and sometimes for broad general reasons-He ought never to do it until he has struggled as hard as he can to find out how the real heart of the principle can be preserved and justice done, and usually, if he struggles hard enough, the desired result is obtained."?

And again, later in the argument:

"All I want to hear from you about is the legal principles as applied principally to the question of whether this should not be treated as a real frustration. If it is not to be treated as a real frus-

'Transcript of Recurd, U. S. C. C. A., p. 404. 
tration, I will find some way to give them those rights and I am not greatly bothered about the various technicalities. They can be reasoned around well enough."'3

When the rule in Paradine v. Jane ${ }^{4}$ was inflexibly followed, it was found that while applicable simplicitcr to the hard and fast requircments of the law affecting real property, it must be modified when applied to the more flexible character of the everchanging manner of men in dealing with one another respecting personal contracts [as distinguished from Real Property contracts], and so the rule can be found changing form under the facts as presented in such cases as Taylor v. Caldwell, ${ }^{5}$ Krell v. Henry, Horlock v. Beal, ${ }^{7}$ etc.

The first is a case where a hired Music Hall was burned before occupancy could be had; the second, where a flat was hired for certain days to view the Coronation procession, which was postponed; and, the third, a suit for wages by a seaman whose English ship was detained by Germany on the outbreat of the War.

How the rule is understood is evidenced not only in the manner of statement, but in the name given to it. This is to be especially remarked in the consideration of the cases we are about to discuss.

The English Courts speak of "The Doctrine of Commercial Frustration," "The Commercial Frustration of the Adventure," "The Putting of an end in a commercial sense to a commercial speculation." The Courts of the United States refer to what has been said to be the identical rule, as the doctrine of "Impossibility of Performance," or of "Supervening Impossibility of Performance."

The word "frustration" does not connote impossibility, and the cases even in the United States Courts where the rule has been applied, are not all cases where performance of the contract

Id., p. 4Ir.

-Aleyn 26 (Eng. 1647).

3 B. \& S. 826 (Eng. 1863).

- L. R. (1903), 2 K. B. 740 (Eng.).

'L. R. (1916), I A. C. 486 (Eng.). 
was rendered actually impossible, but only rendered so difficult of performance as to be regarded as not possible in the eyes of the law, that is to say, not required to be done because impliedly not undertaken to be done.

The American Courts have been slow to adopt the phraseology of the English Courts. The term "frustration" is not found, or, at least, not frequently found, in the language of the American Courts dealing with this phase of contract law.

However, in the opinion of the very able District Judge in the case first above-mentioned, reported under the title "The Isle of Mull,"8 the Court, after speaking of the contract as having become "in a substantial sense impossible," proceeds to inquire if there has been "an actual frustration, either of their mutual purpose or of the purpose of either of them," and later adverts to a conclusive presumption of law involving "a constructive frustration," and still later in the opinion speaks of the "modern doctrine of frustration."

Is there a "modern doctrine of frustration" to be found in the present body of American law, and how far have its limits and boundaries been defined?

Regardless of the terminology, the American Courts have treated the effect of certain subsequent events on the obligation of performance on one side or the other of a contract, as either to defeat or to frustrate the intention of the parties, and, therefore, to nullify the obligations of the contract.

This view of the American Courts finds authoritative expression in the case of the "Kronprinzessin Cecilie." The contract there was to deliver specie upon the terms and for the freight monies agreed upon. It was as absolute a covenant as the one in Paradine v. Jane, supra, because the Court refused to apply the Restraint of Princes Clause as stretching it beyond its literal intent, but the Court found that the parties had impliedly undertaken that the covenant would not be performed in the event which indicated a commercial frustration of the enterprise.

. 244 U. S. I2 (1917). 
And it is well to remark here that the event which went to defeat, in a commercial sense, the performance of the contract, was one which affected the performance of the contract by one of the parties only. It was in evidence that the freight had been paid and that the contract could have been performed by steaming the ressel under forced draft to Plymouth; but the Court held, in effect, that though the performance of the contract was still possible by the defendant, the common sense of the situation required the conelusion that performance was defeated in a commercial sense.

The result of this decision is entirely proper, but the application of the rule thus evolved and enunciated as the rule of common sense does not seem to find ready response in all the Courts.

The recent decisions of the District Court for the Eastern District of Maryland, known as the Baltimore Coal Cases, ${ }^{10}$ seem to revert to the rule as applied previous to the decision in the "Kronprinzessin Cecilie," and rest upon the theory of Impossibility of Performance, and where there was a showing of a possibility of performance, to leave the parties to the contract to their bargain regardless of whether or not, in a commercial sense, the event which went to defeat the object of the parties, was one which, from a common sense viewpoint, rendered the commercial object of the contract frustrate.

In the Baltimore Coal Cases, supra, the contracts were wholly executory, and changing economic conditions, entirely beyond the control of the parties [largely influenced by Governmental regulation], had presented such a wide difference in the aspect of affairs at the time fixed for performance that it was scarcely open to serious question that the parties at the time of making the contract would have agreed together, in the phrase of one of the English Judges-" If that happen, then all is over between us."

But the Court ignored the question of frustration in a commercial sense and founded its decision on the fact of possibility

* Romney. v. MfeNeil, 273 Fed. 287 (Ig2I); Western Counties Shipping Co. V. Mclieil, 273 Fed. 298 (1921); Hellenic Transport Steamship Co. MciNeil, 273 Fed. 290 (Igar); Compagne Navigazione Sota v. Diamond Fuel Co., 273 Fed. 299 (1921); Canute v. Diamond Fuel Co., 273 Fed. 301 (Iger). 
or impossibility of performance, deciding the question on what it was found that others, not similarly situated, found it possible to do under different circumstances and conditions. Certainly little consideration was given to the English thought, as expressed by Maule, J., in Moss v. Smith:11

"In matters of business a thing is said to be impossible when it is not practicable, and a thing is impracticable when it can only be done at an excessive or unreasonable cost";

or to the still later thought, expressed by Lord Parmoor in the . Metropolitan Water Board Case: ${ }^{12}$

"The real meaning and purport of such a contract is that works shall be carried out at prices fixed with reference to the then outlook for cost of labour, plant, and material, spread over a defined limit of time, which could not fail to affect materially the figures inserted by any contractor in sending in his tender."

It is true that the English Pre-War Contract Conmittee's Report ${ }^{13}$ provides that mere increased cost should not be sufficient, but adds the significant words "unless to an enormous and extravagant extent," or unless "the pecuniary burden is so great as to approximate to physical prevention."

No American case has apparently considered the question of increased cost as in any degree an available defence, no matter how enormous or extravagant, and in the consideration of what may defeat the objects of the parties, the pendulum would seem to swing backward and forward. .

The "Kronprinzessin Cecilie,"-decided by the Supreme Court on May 7, 1917, apparently was not before the District Couri in New York, in the decision on May 28, 1917, of "The Themis,"14 when the Court decided that mere financial loss, however serious, could not affect the obligations of the parties to a contract.

129 C. B. 94 (1850), cited by Lord Blackburn in Dahil v. Nelson, L. R, 6 A. C. 38 (188I), at page 52.

L. R. (1918), I A. C. I19.

" Sec. 10, Ca. 8975, of 1978

"214 Fed. 545 (1917). 
In that case the slide in the Panana Canal presented a subsequent change in the situation which materially affected the contract of the parties, although the Court gave the fact no effect.

But the Baltimore Coal Cases, supra, really involved the transportation of a large quantity of coal at fixed prices to foreign customers, some of whom, indeed, were Governmental agencies, and although the contracts for transportation took the form of charter parties on individual ships, they were in reality tonnage contracts, and were not in the nature of time charter parties, and were not to be ruled by those cases which hold that, despite the inteference with the use of the ship, the charterer is still able, and therefore required, to pay the money due on the charter hire under his corenant to do so. 15

The unprecedented rise, to extravagant heights, of the cost of coal, the extraordinary concentration of hundreds of vessels at the coal loading ports on the North Atlantic, the consequent rapid and disproportionate fall in the price of tonnage, and the subsequent cancellation of contracts and commitments on the part of European buyers, incident to the extraordinarily rapid change in all the factors of the trade, produced a situation materially affecting the figures on which all costs were based in the contracts made by the contractor, and presented an enormous and extravagant difference in the pecuniary burden of the coal contractor, certainly great enough to approximate physical prevention, and in reality rendered it financially, if not also physically, impossible for the coal contractor to fulfill his commitments; yet these facts, one or all, singly or together, were apparently given no consideration in the judicial decision of the District Judge to hold the contractor liable on his covenants.

But certain it seems to be that there is a "modern doctrine of frustration" in the American law. The very language of the Circuit Court of Appeals for the Third Circuit, in certifying the questions involved to the Supreme Court in Allanwilde Transport Corporation v. Vacuum Oil Company, ${ }^{10}$ indicates this clearly.

"Clyde, ctc., S. S. Co. v. West India S. S. Co., 16g Fed. 275 (1909).

${ }^{*} 248$ U. S. 377 (1919). 
The first question was:

"Was the adventure frustrated, and was the contract evidenced by the charter-party and by the bill of lading issued to the Oil Company dissolved, so as to relieve the carrier from further obligation to carry the oil?"

The third question propounded was in the same form:

"Was the adventure frustrated, and was the contract evidenced by the bill of lading issued to Pidwell dissolved, so as to relieve the carrier from further obligation to carry the nails?

The Supreme Court answers the questions in the affirmative and says that:

"The condition was, therefore, so far permanent as naturally and justifiably to determine business judgment and action depending upon it."

It clearly follows from this that the Courts will regard the conditions submitted to them in a particular case, and will decide the question of frustration with a view to the facts that "determine business judgment and action depending upon it"

This certainly is a wide departure from the earlier harsh rule in Paradine v. Jane, supra, and seems more consonant with good judgment and sound sense.

But what the limits of the rule are cannot be stated. The doctrine is still a growing one, and perhaps not yet fully recognized in the Courts of First Instance in this country, but it is a proper one, and its limits will finally be determined in the course of the consideration of the various cases that will arise for authoritative decision by the Appellate Courts of this country.

William J. Conlen.

Philadelphia, Pa. 